\title{
THE FIRST FINDINGS OF THE DIFFERENCES IN COMPLETE BLOOD COUNT BETWEEN DIPLOID AND TRIPLOID TENCH, Tinca tinca $\mathrm{L}$.
}

\author{
Z. SVOBODOVÁ, J. KOLÁŘOVȦ, M. FLAJŠHANS
}

Research Institute of Fish Culture and Hydrobiology, University of South Bohemia, Vodñany, Czech Republic

Received July 22, 1998

Accepted September 21, 1998

\begin{abstract}
Svobodová. Z., J. Kolářová, M. Flajšhans: The First Findings of the Differences in Complete Blood Count Between Diploid and Triploid Tench. Tinca tinca L. Acta vet. Bmo 1998, 67: 243-248.

The aim of this work was to evaluate differences in complete blood count of diploid and triploid tench and concentration of total protein in blood plasma of these fish. Haematological examination of 78 specimens of three-year-old tench, consisting of 21 triploids and their 57 diploid siblings was performed in July 1996. Analysis of variance test confirmed a significantly lower erythrocyte count in triploids $(P<0.01)$, as well as a significantly lower haemoglobin content $(P<0.05)$, significantly higher medium corpuscular volume, higher medium corpuscular haemoglobin and lower medium corpuscular haemoglobin concentration (all at $\mathrm{P}<0.01$ ) compared to diploids. The haematocrit value of triploids was insignificantly lower compared to diploids. The differences of erythrocyte nuclear area, perimeter, average size, major axis and aspect ratio between diploids and triploids were found significant at $P<0.01$ and the effect of ploidy level on these dimensions was considered highly significant $(\mathrm{P}<0.0001)$. No effect of ploidy level was proven for erythrocyte nuclear minor axis. The leukocyte count of triploids was insignificantly lesser compared to diploids. Triploid tench were found of significantly lower concentration of total protein in blood plasma compared to diploids $(\mathrm{P}<0.01)$. Triploid tench could be hypothesized to have a lower oxygenation capacity of blood, as well as a lower non-specific immunity level compared to diploids. Insignificantly higher erythrocyte count, haemoglobin content, haematocrit value, and significantly higher concentration of total protein in blood plasma $(\mathrm{P}<0.01)$ was reported for diploid females compared to males.
\end{abstract}

Ploidy level, complete red blood count, erythrocyte nuclear dimensions, leukocyte, total protein

The haematological indices of diploid and triploid fish of various species were compared by several authors, mostly regarding the complete red blood count of salmonids (Benfey and Sutterlin 1984ab; Benfey et al. 1984; Small and Benfey 1987, Nakamura etal. 1989: Tambets etal. 1991; Biron and Benfey 1994; Thomas and Morisson 1995) or of other species mostly with that of cyprinids or silurids (Sezaki et al. 1977; Liu et al. 1978; Wolters et al.1982; Beck and Biggers 1983; Barker et al. 1983; Sezaki et al. 1983; Krasznai et al. 1984: Ueno 1984; Suzuki et al. 1985; Wattendorf 1986; Sezaki et al.1991; Boron 1994). Based on these data, the following values of complete red blood count indices of triploid fish can be generalized: triploids have erythrocytes of larger medium corpuscular volume caused above all by increment in size of the major erythrocyte axis. The differences in both erythrocyte cellular and nuclear dimensions between diploids and triploids are well described (e.g. Swarup 1959; Sezaki and Kobayasi 1978; Lemoine and Smith 1980; Wolters et al. 1982; Benfey et al. 1984; Flajšhans 1997 and others) and used for ploidy level discrimination in many fish species. Triploids have also a lower count of erythrocytes compared to diploids. The haematocrit value of triploids and diploids is similar. The 
amount of haemoglobin of triploids is usually lower than that of diploids. In contrary, the medium corpuscular haemoglobin of triploids is higher compared to diploids. The value of medium corpuscular haemoglobin concentration of erythrocytes of triploids and diploids is stated to be approximately at the same level.

The haematology of diploid tench, Tinca tinca $\mathrm{L}$. was examined by several authors, mostly dealing with seasonal changes in some indices (Einzsporn-Oreck a 1970: S vobodová et al. 1978; Collazos et al. 1993). Data on haematological indices of tench females and males were also reported (Svobodová et al. 1978; Habekovič 1991). From this point of view, tench was also used in studies on pollutant effects and other changes in the aquatic environment (Demael et al. 1980; Kreutzmann 1984; Demael et al. 1984: Al-Sabti 1986) and/or on the effects of three different anaesthetics on fish (S vobodová et al. 1988).

To the best of our knowledge, no references concern haematological comparison of diploid and triploid tench but the very first brief communication on image analysis of erythrocyte nuclei by Flajšh ans (1996). The aim of this paper is to report on the results of haematological investigation of tench of both ploidy levels.

\section{Materials and Methods}

Triploid tench were produced at the authors' workplace, by cold shock as described by Flajšhans et al. (1993). Three-year-old triploids and their diploid siblings were sampled from pond performance tests. in total of 78 specimen, consisting of 21 triploids ( $138.6 \pm 7.96 \mathrm{~g}$ body weight) and 57 diploids $(173.3 \pm 5.73 \mathrm{~g} \mathrm{bw})$ in July 1996.

Blood was sampled from the caudal vessel into a heparinized syringe. The following indices were determined according to Svobodová et al. (1986): erythrocyte count (Er), haematocrit value (PCV), haemoglobin content $(\mathrm{Hb})$, mean corpuscular volume $(\mathrm{MCV})$, mean corpuscular haemoglobin $(\mathrm{MCH})$ and mean corpuscular haemoglobin concentration (MCHC). Erythrocyte nuclear dimensions (area, perimeter, average nuclear size. major axis, minor axis) were measured by microscope-coupled computer-assisted image analysis according to Flajšhans (1997). Aspect ratio was chosen as an additional index and computed as a ratio of minor axis: major axis.

Moreover. leukocyte count (Leuco) and concentration of total protein in blood plasma (TP) were determined according to Svobodová et al. (1986) with the latter index assessed refractometrically.

In order to test the effect of the ploidy level (diploidy vs. triploidy) and/or of the sex in diploids (female vs. male) on values of the respective haematological indices statistically, the analysis of variance (ANOVA) in Statgraphics 5.0 was used.

\section{Results}

Values of the respective haematological indices of diploid and triploid tench are given in Table 1. In triploids compared to diploids, there was evident a significantly lower erythrocyte count (ANOVA, $\mathrm{P}<0.01$ ), haemoglobin content (ANOVA, $\mathrm{P}<0.05$ ) and mean corpuscular haemoglobin concentration (ANOVA, $\mathrm{P}<0.01$ ), whereas the mean corpuscular volume and mean corpuscular haemoglobin were higher (ANOVA, $\mathrm{P}<$ 0.01 ). The haematocrit value of triploids was insignificantly lower (ANOVA, P > 0.05) compared to diploids. The differences of erythrocyte nuclear area, perimeter, average size, major axis and aspect ratio between diploids and triploids were found significant at $P<0.01$ (ANOVA) and the effect of ploidy level on these dimensions was considered highly significant (ANOVA, $P<0.0001$ ). No effect of ploidy level was proven for the dimension of erythrocyte nuclear minor axis (ANOVA, P > 0.05). Erythrocyte nuclei of triploid tench were found slightly more eliptic (Fig. 1). The leukocyte count of triploids was insignificantly lower (ANOVA, P > 0.05) compared to diploids. Triploids were found to have expressively lower concentration of total protein in blood plasma compared to diploids (ANOVA, $\mathrm{P}<0.01$ ). 
Table 1

Body weight, indices of complete red blood count, erythrocyte nuclear dimensions, leukocyte count and total protein concentration in blood plasma of diploid and triploid tench (Tinca tinca L.) under study

\begin{tabular}{|l|c|c|c|c|c|c|}
\hline \multirow{2}{*}{ Indices } & \multirow{2}{*}{ Unit } & \multicolumn{2}{|c|}{ Diploids } & \multicolumn{2}{|c|}{ Triploids } & \multirow{2}{*}{$\begin{array}{c}\text { Statistical } \\
\text { significance }\end{array}$} \\
\cline { 3 - 6 } & & $\mathrm{n}$ & mean $\pm \mathrm{SD}$ & $\mathrm{n}$ & mean $\pm \mathrm{SD}$ & $\mathrm{P}<0.01$ \\
\hline Body Weight & $\mathrm{g}$ & 57 & $173.30 \pm 5.73$ & 21 & $138.60 \pm 7.96$ & $\mathrm{P}<0.01$ \\
$\mathrm{Er}$ & $\mathrm{T} \cdot \mathrm{l}^{-1}$ & 36 & $1.34 \pm 0.05$ & 16 & $0.92 \pm 0.04$ & \\
$\mathrm{PCV}$ & $\mathrm{l} \cdot \mathrm{l}^{-1}$ & 52 & $0.34 \pm 0.01$ & 20 & $0.32 \pm 0.02$ & \\
$\mathrm{Hb}$ & $\mathrm{g} \cdot \mathrm{l}^{-1}$ & 52 & $79.80 \pm 2.48$ & 19 & $69.90 \pm 4.03$ & $\mathrm{P}<0.05$ \\
$\mathrm{MCV}$ & $\mathrm{fl}$ & 36 & $254.00 \pm 7.38$ & 16 & $355.00 \pm 17.60$ & $\mathrm{P}<0.01$ \\
$\mathrm{MCHC}$ & $\mathrm{fl} \mathrm{l}^{-1}$ & 52 & $0.24 \pm 0.004$ & 19 & $0.22 \pm 0.006$ & $\mathrm{P}<0.01$ \\
MCH & $\mathrm{mmol} \cdot \mathrm{l}^{-1}$ & 36 & $60.70 \pm 1.74$ & 16 & $75.30 \pm 4.65$ & $\mathrm{P}<0.01$ \\
Nuclear Area & $\mu \mathrm{m}^{2}$ & 57 & $10.58 \pm 1.28$ & 21 & $16.50 \pm 1.71$ & $\mathrm{P}<0.01$ \\
Nuclear Perimeter & $\mu \mathrm{m}$ & 57 & $12.44 \pm 0.81$ & 21 & $15.78 \pm 0.94$ & $\mathrm{P}<0.01$ \\
Average Nuclear Size & $\mu \mathrm{m}$ & 57 & $4.00 \pm 0.24$ & 21 & $5.05 \pm 0.23$ & $\mathrm{P}<0.01$ \\
Nuclear Major Axis & $\mu \mathrm{m}$ & 57 & $4.67 \pm 0.38$ & 21 & $6.06 \pm 0.49$ & $\mathrm{P}<0.01$ \\
Nuclear Minor Axis & $\mu \mathrm{m}$ & 57 & $3.19 \pm 0.30$ & 21 & $3.75 \pm 0.37$ & \\
Aspect Ratio & - & 57 & $0.69 \pm 0.09$ & 21 & $0.63 \pm 0.09$ & $\mathrm{P}<0.01$ \\
Leuco & $\mathrm{G} \cdot \mathrm{l}^{-1}$ & 47 & $62.20 \pm 5.52$ & 20 & $58.20 \pm 7.40$ & \\
TP & $\mathrm{g} \cdot \mathrm{l}^{-1}$ & 52 & $14.80 \pm 1.11$ & 20 & $8.70 \pm 1.53$ & $\mathrm{P}<0.01$ \\
\hline
\end{tabular}

Table 2

Body weight, indices of complete red blood count, leukocyte count and total protein concentration in blood plasma of diploid females and males of tench (Tinca tinca L.) under study

\begin{tabular}{|c|c|c|c|c|c|c|}
\hline \multirow{2}{*}{ Indices } & \multirow{2}{*}{ Unit } & \multicolumn{2}{|c|}{ Females } & \multicolumn{2}{|r|}{ Males } & \multirow{2}{*}{$\begin{array}{c}\text { Statistical } \\
\text { Significance }\end{array}$} \\
\hline & & $\mathrm{n}$ & mean $\pm S D$ & $\mathrm{n}$ & mean $\pm S D$ & \\
\hline Body Weight & $\mathrm{g}$ & 16 & $174.10 \pm 6.59$ & 18 & $156.30 \pm 5.60$ & $P<0.05$ \\
\hline $\mathrm{Er}$ & $\mathrm{T} \cdot \mathrm{l}^{-1}$ & 15 & $1.30 \pm 0.077$ & 16 & $1.42 \pm 0.079$ & \\
\hline PCV & $1 \cdot 1^{-1}$ & 16 & $0.33 \pm 0.022$ & 17 & $0.38 \pm 0.019$ & \\
\hline $\mathrm{Hb}$ & $g \cdot l^{-1}$ & 16 & $78.60 \pm 4.18$ & 17 & $85.40 \pm 4.33$ & \\
\hline $\mathrm{MCV}$ & $\mathrm{fl}$ & 15 & $244.00 \pm 9.60$ & 16 & $268.00 \pm 10.80$ & \\
\hline $\mathrm{MCHC}$ & $1 \cdot 1^{-1}$ & 16 & $0.25 \pm 0.007$ & 17 & $0.23 \pm 0.005$ & \\
\hline $\mathrm{MCH}$ & $\mathrm{mmol} \cdot \mathrm{l}^{-1}$ & 15 & $61.90 \pm 3.41$ & 16 & $60.60 \pm 1.91$ & \\
\hline Leuco & $\mathrm{G} \cdot \mathrm{l}^{-1}$ & 15 & $54.80 \pm 9.00$ & 16 & $73.80 \pm 12.60$ & \\
\hline $\mathrm{TP}$ & $g \cdot l^{-1}$ & 16 & $18.70 \pm 2.39$ & 17 & $11.70 \pm 1.01$ & $\mathrm{P}<0.01$ \\
\hline
\end{tabular}

Table 2 shows the body weight and the haematological indices of diploid tench females and males. Body weight was higher for females compared to males (ANOVA, P < 0.05). There was found a higher erythrocyte count, haemoglobin content and haematocrit value of males compared to females. However, these differences were found insignificant (ANOVA, $P>0.05)$. Similarly, no significant differences between both sexes were found in other indices of complete red blood count ( $\mathrm{MCV}, \mathrm{MCH}, \mathrm{MCHC})$. Insignificantly higher leukocyte count was found in males compared to females (ANOVA, P > 0.05). In contrary, a significantly higher concentration of total protein in blood plasma of females was found compared to that of males (ANOVA, $\mathrm{P}<0.01$ ). 


\section{Discussion}

To our knowledge. no data on the haematology of triploid tench are available. Comparing our results with those on triploid salmonids, other triploid cyprinids (common carp, Cyprinus carpio L.. and herbivorous cyprinids) and triploid silurids, there is a good accordance with the data of Barker et al. (1983), Benfey and Sutterlin (1984a), Krasznai et al. (1984). Ueno (1984), Wattendorf (1986), Small and Benfey (1987), Flajšh ans (1997) and others. Data on tench erythrocyte nuclear dimensions do not differ from those preliminarily published by Flajšhans (1996).

Based on significantly lower values for haemoglobin content and $\mathrm{MCHC}$ we could anticipate triploid tench to have a lower oxygenation capacity of blood compared to the diploid ones. Such a lower oxygenation capacity of blood that would appear in fish above all after exposure to stress, was reported e. g. for triploid rainbow trout (Oncorhynchus mykiss) by Virtanen et al. (1990), for triploid Atlantic salmon (Salmo salar) by Benfey and Sutterlin (1984b) and for triploid brook trout (Salvelinus fontinalis) by Stilwell and Benfey (1996).

Considering the lower leukocyte count and especially the markedly lower concentration of total protein in blood plasma of triploids, we suppose that triploids have a lower nonspecific immunity level compared to diploids. Examination of the non-specific immunity of tench of both ploidy levels would be highly desirable for the future, since such data are missing in the literature. Moreover, they are not stated in studies of triploids of other fish species except for triploid rainbow trout by Yamamoto and Iida (1994), stating nonspecific defence activities based on chemiluminiscence determination of whole blood stimulated by zymosan.

The sex-related differences in values of complete red blood count of tench are in accordance with data of Einzsporn-Orecka (1970), Svobodová et al. (1978), Habekovič (1991). as well as with those for common carp (Svobodová 1973), northern pike, Esox lucius (Črvinka and Pecha 1975; Hamáčková et al. 1975) and several other fish species. In all these cases, insignificantly or significantly higher erythrocyte count, haemoglobin content and haematocrit value were recorded for males as compared to females. Such increased levels in males are associated with a more intensive metabolism of males (Stroganov 1962). As found for common carp and tench (Svobodová 1973) this sex-related difference does not maintain the same level throughout the whole year: it is observed in certain periods only, and during some time of the year the difference in complete red blood count is insignificant or there is no difference at all. This is associated with the annual cycle of gonadal development.

There was recorded about $7 \mathrm{~g} \cdot \mathrm{l}^{-1}$ more total protein in tench females compared to males. A similar highly significant sex-related difference was recorded in wels, Silurus glanis L. $\left(6 \mathrm{~g} \cdot \mathrm{l}^{-1}, \mathrm{Svobodová}\right.$ et al. 1981). Protein concentration in blood plasma is associated very closely to the sedimentation rate of erythrocytes (Karásek et al. 1960). Such a significantly higher erythrocyte sedimentation rate in tench females than in males was found by Habekovič (1991). This would refer to a higher protein concentration in blood plasma of females.

\section{Odlišnosti krevního obrazu diploidních a triploidních línů, Tinca tinca L. - první nálezy}

Cílem práce bylo posoudit rozdíly v červeném krevním obrazu diploidních a triploidních línů a rozdíly $\mathrm{v}$ počtu leukocytů a $\mathrm{v}$ obsahu celkových bílkovin $\mathrm{v}$ krevní plazmě $\mathrm{u}$ těchto ryb. Hematologické vyšetření bylo provedeno u 78 kusů třiletých línů obecných, 
z toho u 21 triploidů a jejich 57 diploidních sourozenců v červnu 1996. Analýzou variance byl u triploidních línů potvrzen signifikantně nižší počet erytrocytů $(\mathrm{P}<0.01)$, nižší obsah hemoglobinu $(\mathrm{P}<0.05)$, vyšši střední objem erytrocytů, nižši střední barevná koncentrace a vyšší hodnota hemoglobinu v erytrocytu (vše na hladině $\mathrm{P}<0.01$ ) ve srovnání s diploidy. Hematokritová hodnota byla u triploidů nevýznamně nižší ve srovnání s diploidními líny ( $\mathrm{P}>0.05$ ). Rozdíly ve velikosti plochy jádra erytrocytu, obvodu jádra, jeho průměrné velikosti, délce dlouhé osy a $\mathrm{v}$ poměru os jádra mezi diploidy a triploidy byly shledány signifikantními na úrovni $\mathrm{P}<0.01$ a vliv ploidie na tyto rozměry byl shledán vysoce významným $(\mathrm{P}<0.0001)$. Nebyl prokázán vliv ploidie na délku krátké osy jádra erytrocytu. Počet leukocytů byl u triploidů nevýznamně nižší ve srovnání s diploidními líny $(\mathrm{P}>0.05)$. U triploidních línů byl naměřen vysoce signifikantně nižší obsah celkových bílkovin v krevní plazmě ve srovnání s diploidními líny $(\mathrm{P}<0.01)$. Na základě naměřených parametrů lze u triploidů předpokládat nižší oxygenační kapacitu krve a nižší úroveň nespecifické imunity ve srovnání s diploidy. Ve shodě s literárními údaji byl zjištěn nevýznamně vyšší počet erytrocytů, množství hemoglobinu, hematokritová hodnota, vyšši počet leukocytů $(\mathrm{P}>0.05)$ a vysoce signifikantně vyšší koncentrace celkových bílkovin v krevní plazmě $(\mathrm{P}<$ $0.01)$ jikernaček ve srovnání s mlíčáky diploidních línů.

\section{Acknowledgements}

This research was supported as Project No. EP6051 by the National Agency of Agricultural Research, Ministry of Agriculture of the Czech Republic.

The authors' thanks are due to Mrs. Anna Kơcová and Mrs. Marie Pečená. both of the authors' institute, for technical assistance.

\section{References}

AL-SABTI, K. 1986: Comparative micronucleated erythrocyte cell induction in three cyprinids by five carcinogenic-mutagenic chemicals. Cytobios 47: 147-154

BARKER, C. J., BECK, M. L., BIGGERS, C. J. 1983: Hematologic and enzymatic analysis of Ctenopharyngodon idella $\times$ Hypophthalmichthys nobilis F sub(1) hybrids. Comp. Biochem. Physiol. 74A: 915-918

BECK, M. L., BIGGERS, C. J. 1983: Erythrocyte measurements of diploid and triploid Ctenopharyngodon idella $\times$ Hypophthalmichthys nobilis hybrids. J. Fish. Biol. 22: 497-502

BENFEY, T. J., SUTTERLIN, A. M. 1984a: The haematology of triploid landlocked Atlantic salmon. Salmo salar L. J. Fish Biol. 24: 333-338

BENFEY. T. J., SUTTERLIN, A. M. 1984b: Oxygen utilization by triploid landlocked Atlantic salmon (Salmo salar $\mathrm{L}$ ). Aquaculture 42: 69-73

BENFEY, T. J., SUTTERLIN. A. M., THOMPSON, R. J. 1984: Use of erythrocyte measurements to identify triploid salmonids. Can. J. Fish Aquat. Sci. 41: 980-984

BIRON. M.. BENFEY. T.. J., 1994. Cortisol. glucose and hematocrit changes during acute stress, cohort sampling, and the diel cycle in diploid and triploid brook trout (Salvelinus fontinalis Mitchill). Fish Physiol. Biochem. 13: 153-160

BORON, A.. 1994. Use of erythrocyte measurements to detect natural triploids of spined loach Cobitis taenia (L.). Cytobios 78: 197-202

COLLAZOS, M. E.. BARRIGA. C., DE SANDE, F.. ORTEGA, E. 1993: Variaciones estacionales e influencia del sexo sorbe diversos parametros sanguineos del ciprinido Tinca tinca. In: CERVINO, A. et al.: Acta del IV. Congreso National de acuicultura Spain. pp. 173-178

CERVINKA. S., PECHA. O. 1975: Hematologické hodnoty a celková bílkovina v krevním séru štiky obecné (Esox lucius $\mathrm{L}$.) z rybničního chovu v období po výtěru. Živoč. výroba 20: 861-86+ (in Czech)

DEMAEL. A., GARIN. D., PERES, G. 1980: Response of the tench (Tinca tinca L.) to potassium nitrate enriched water. J. Fish Biol. 16:15-22

DEMAEL. A.. GUSTIN, P., LEPOT. D. 1984: Influence d'une baisse moderée du pH de l'eau sur quelques activites enzymatiques du foie et sur certains composants sanguins de la tanche (Tinca tinca L.). Ichthyophysiol. Acta 8: $75-91$

EINSZPORN-ORECKA, T. 1970: Quantitative changes in the circulating blood of tench (Tinca tinca $\mathrm{L}$.) in the annual cycle. Pol. Arch. Hydrobiol. 17: 435-444 
FLAJŠHANS. M. 1996: Ploidy level determination in tench (Tinca tinca L.; Pisces: Cyprinidae) by computerassisted image analysis of ery throcyte nuclei. In: KAPOUN. K. Proc. DIPS` 96 Digital Image Processing, Univ. South Bohem., Ceské Budějovice. pp. 55-56

FLAJŠHANS. M. 1997: A model approach to distinguish diploid and triploid fish by means of computer-assisted image analysis. Acta vet. Brno 66: 101-110

FLAJŠHANS, M., LINHART, O., KVASNICKA, P. 1993: Genetic studies of tench (Tinca tinca L.): induced triploidy and tetraploidy and first performance data. Aquaculture 113: $301-312$

HABEKOVIČ, D. 1991: The hematologic characteristics of sexual dimorphism of tench (Tinca tinc $a$ L.) during spawning period. Ichthyologia 23: 17-24

HAMÁČKOVÁ. J.. SVOBODOVÁ. Z.. KOUŘIL. J. 1975: Hematologické hodnoty štiky obecné (Esox lucius L.) z rybničního chovu v predvýtěrovém období. Żivoč. výroba 20: 851 -859 (in Czech)

KARÁSEK. F. et al. 1960: Učebnice fýziologie pro studující lékařství. SZN Praha, 560 p. (in Czech)

KRASZNAI, Z., MARIAN, T.. JENEY.Z.. JENEY. G.. ZSIGRI. A. 1984: Effect of triploidy on the blood cell size of hybrid grass carp. Aquacult. Hung. 4: 17-24

KREUTZMANN. K. L. 1984: Ergebnisse zur Morphologie der Erythrozytenreihe gesunder und belasteter Fische. Z. Binnenfisch. D.D.R. 31: 167-172

LEMOINE. L. H.. SMITH, T. L. 1980: Polyploidy induced in brook trout by cold shock. Trans. Am. Fish. Soc. 109: $626-631$

LIU, S., SEZAKI. K.. HASHIMOTO. K., KOBAYASI. H., NAKAMURA. M. 1978: Simplified techniques for determination of polyploidy in ginbuna Carassius auratus langsdorfi. Bull. Jap. Soc. Sci. Fish. 44: 601-606

NAKAMURA. S., IMAI, N., OHYA. S., KOBAYASI, H. 1989: Oxygen uptake rate and hematological characteristics in triploid amago salmon, Oncorhynchus masou macrostomus. Mem. Fac. Agric. Kinki univ. 22: 31-38

SEZAKI, K.. KOBAYASI, H. 1978: Comparison of erythrocytic size between diploid and tetraploid in spinous loach. Cobitis biwae. Bull. Jap. Soc. Sci. Fish.. 44: 851-854

SEZAKI. K., KOBAYASI, H., NAKAMURA, M. 1977: Size of erythrocytes in the diploid and triploid specimens of Carassius auratus langsdorfi. Jap. J. Ichthyol. 24: 135-140

SEZAKI, K., WATABE, S., HASHIMOTO, K. 1983: A comparison of chemical composition between diploids and triploids of ,ginbuna“ Carassius auratus langsdorfi. Bull. Jap. Soc. Sci. Fish. Nissuishi 49: 97-101

SEZAKI, K., WATABE. S., TSUKAMOTO, K., HASHIMOTO, K. 1991: Effects of increase in ploidy status on respiratory function of ginbuna Carassius auratus langsdorfi (Cyprinidae). Comp. Biochem. Physiol. 99A: 123-127

SMALL, S.. A.,BENFEY, T., J. 1987: Cell size in triploid salmon. J. Exp. Zool. 241: 339-342

STILWELL, E. J., BENFEY, T. J. 1996: The swimming performance of triploid brook trout (Salvelinus fontinalis). Bull. Aquacult. Assoc. Can. 96: 41-43

STROGANOV, N. S. 1962: Ekologičeskaja fiziologija ryb. Izd. Moskow. univer., 443 p. (in Russian)

SUZUKI, R., NAKANISHI, T., OSHIRO, T. 1985: Survival, growth and sterility of induced triploids in the cyprinid loach Misgumus anguillicaudatus. Bull. Jap. Soc. Sci. Fish. Nissuishi 51: 889-894

SVOBODOVÁ, Z. 1973: Influence of sex upon certain haematological parameters of the carp (Cyprinus carpio L.) during the third vegetation period. Acta vet. Brno 42: 257-263

SVOBODOVÁ, Z., KOÚRIL, J., HAMÁCKKOVÁ, J. 1978: The values of some haematological parameters in parent tench (Tinca tinca). Żivoč. výroba 23: 825-833 (in Czech)

SVOBODOVÁ, Z., KOUŘIL, J., HAMÁČKOVÁ, J. 1981: Vliv pohlaví na některé hematologické a biochemické hodnoty u ryb. Sborník referátů konference Reprodukce, genetika a hybridizace ryb, Vodňany, s. $11-17$ (in Czech)

SVOBODOVÁ. Z.. PRAVDA, D., PALÁČKOVÁ, J. 1986: Jednotné metody hematologického vyక̌etřování ryb. Edice metodik VÚRH Vodňany, 22, 36 s. (in Czech)

SVOBODOVÁ, Z., VALENTOVÁ, V., KOUŘIL, J., VYKUSOVÁ, B., HAMÁCKKOVÁ, J. 1988: Porovnání vlivu tři anestetik na některé hematologické ukazatele a acidobazickou rovnováhu lína. Bul. VÚRH Vodñany 24: 10-17

SWARUP. H. 1959: Effect of triploidy on the body size, general organization and cellular structure in Gasterosteus aculeatus (L.). J. Genet. 56: 143-155

TAMBETS. J.. PAAVER, T., PALM, A., PIHLAK, A., GROSS, R. 1991: Variability of some cell indices in diand triploid rainbow trout Oncorhynchus mykiss R. Proc. Est. Acad. Sci. Biol. 40: 129-135

THOMAS. P.. MORRISON, R. 1995: A method to assess triploidy in swim-up rainbow trout. Austasia Aquacult. 9: $62-63$

UENO. K. 1984: Induction of triploid carp and their haematological characteristics. Jpn. J. Genet. 59: 585-591

VIRTANEN, E.. FORSMAN. L., SUNDBY, A. 1990: Triploidy decreases the aerobic swimming capacity of rainbow trout (Salmo gairdneri). Comp. Biochem. Physiol. 96: 117-121

WATTENDORF, R. J. 1986: Rapid identification of triploid grass carp with Coulter Counter and Channelyzer. Prog. Fish. Cult. 48: 125-132

WOLTERS. W. R., CHRISMAN, C. L., LIBEY, G. S. 1982: Erythrocyte nuclear measurements of diploid and triploid channel catfish. Ictalurus punctatus (Rafinesque). J. Fish Biol. 20: 253-258

YAMAMOTO, A.. IIDA. T. 1994: Non-specific defense activities of triploid rainbow trout. Int. Symp. on Aquatic Animal Health. Abstracts. School of Vet. Med. Univ. California, USA, p. 74 
Plate I.

Svobodová Z. et al.: The first findings... pp. 243-248.

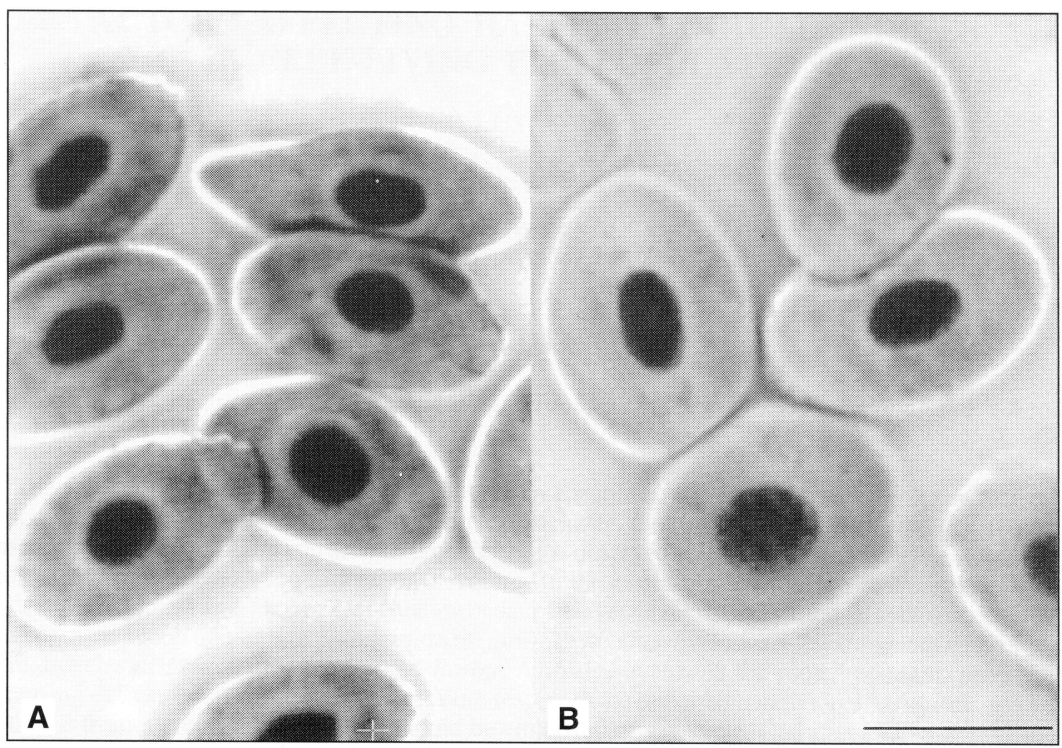

Fig. 1. Videoprintout of a computerized dark field microscopic image of erythrocytes of a diploid (A) and a triploid (B) tench, Tinca tinca L. Objective Olympus NCSPlan Dry 100×. Bar indicates $10 \mu \mathrm{m}$. 